\title{
PENINGKATAN KESTABILAN ENZIM $\alpha$-AMILASE DENGAN PENAMBAHAN GLISEROL
}

\author{
Yandri $^{1}$, Nurul Nadila ${ }^{1}$, Tati Suhartati ${ }^{1}$, Heri Satria ${ }^{1}$ dan Sutopo Hadi ${ }^{1}$ \\ ${ }^{1}$ Jurusan Kimia Fakultas MIPA Universitas Lampung, Jl. Sumantri Brojonegoro \\ No. 1, Bandar Lampung, Indonesia \\ yandri.as@fmipa.unila.ac.id
}

Artikel Info
Diterima
tanggal
21.08 .2020
Disetujui
publikasi
tanggal
30.10 .2020
Kata kunci :
$\alpha$-amilase,
Aspergillus
fumigatus,
gliserol, zat
aditif

\begin{abstract}
ABSTRAK
Enzim $\alpha$-amilase adalah enzim yang mengkatalisis hidrolisis ikatan $\alpha-1,4$ glikosidik polisakarida menghasilkan dekstrin, oligosakarida, maltosa, dan Dglukosa. Penelitian ini bertujuan meningkatkan kestabilan enzim $\alpha$-amilase hasil pemurnian dari Aspergillus fumigatus dengan penambahan gliserol. Aktivitas enzim ditentukan dengan metode Fuwa dan Mandels, sedangkan kadar protein ditentukan dengan metode Lowry. Hasil penelitian menunjukkan enzim hasil pemurnian memiliki aktivitas spesifik sebesar 1,377 U/mg meningkat sebanyak 8,1 kali dibandingkan dengan ekstrak kasar enzim yang memiliki aktivitas spesifik sebesar $0,170 \mathrm{U} / \mathrm{mg}$. Enzim hasil pemurnian memiliki pH optimum 5,5; suhu optimum 55 ${ }^{\circ} \mathrm{C}$; waktu paruh 133,26 menit. Enzim setelah penambahan gliserol 0,5; 1 dan 1,5 M memiliki $\mathrm{pH}$ optimum dan suhu optimum yang sama, yaitu $\mathrm{pH} 5,5$ dan suhu $55^{\circ} \mathrm{C}$. Enzim setelah penambahan gliserol: $0,5 \mathrm{M}$ memiliki waktu paruh 157,5 menit: $1 \mathrm{M}$ memiliki waktu paruh 182,36 menit, dan 1,5 M memiliki waktu paruh 223,54 menit. Penambahan gliserol pada enzim $\alpha$-amilase hasil pemurnian dari A. fumigatus dapat meningkatkan kestabilan enzim sebanyak 1,2-1,7 kali dibandingkan dengan enzim hasil pemurnian yang ditunjukkan dengan peningkatan waktu paruh.
\end{abstract}

\section{ABSTRACT}

The $\alpha$-amylase is an enzyme that catalyzes the hydrolysis of $\alpha-1,4$ polysaccharide glycosidic bonds to produce dextrins, oligosaccharides, maltose, and D-glucose. This study aims to increase the stability of the purified $\alpha$-amylase isolated from Aspergillus fumigatus by the addition of glycerol. The enzyme activity was determined by the Fuwa and Mandels method, while the protein content was determined by the Lowry method. The results showed that the purified enzyme had a specific activity of $1.377 \mathrm{U} / \mathrm{mg}$, an increase of 8.1 times compared to the crude extract of the enzyme which had a specific activity of 0.170 $\mathrm{U} / \mathrm{mg}$. The purified enzyme has an optimum $\mathrm{pH}$ of 5.5; optimum temperature of $55{ }^{\circ} \mathrm{C}$; half-life 133.26 min. The enzyme resulted from the addition of 0.5 glycerol; 1 and $1.5 \mathrm{M}$ have the same optimum $\mathrm{pH}$ and optimum temperature, namely $\mathrm{pH} 5.5$ and temperature $55^{\circ} \mathrm{C}$. The enzyme with the addition of glycerol: $0.5 \mathrm{M}$ has a half-life of $157.5 \mathrm{~min}: 1 \mathrm{M}$ has a half-life of 182.36 minutes, and $1.5 \mathrm{M}$ has a half-life of 223.54 mins. The addition of glycerol to the purified $\alpha$-amylase from A. fumigatus can increase the stability of the enzyme 1.2-1.7 times compared to the purified enzyme as indicated by an increase in halflife.

doi: http://dx.doi.org/10.23960/aec.v5.i2.2020.p143-154 


\section{PENDAHULUAN}

Enzim amilase merupakan salah satu jenis enzim yang banyak digunakan dalam bidang industri dan memiliki aplikasi yang sangat luas dalam bidang industri (Irdawati dkk., 2015). Enzim $\alpha$-amilase ( $\alpha$-1,4-glukan-4-glukanohidrolase, EC 3.2.1.1) mengkatalisis pemutusan ikatan a-D-(1,4)-glukosidik pada pati, glikogen, dan oligosakarida menghasilkan dekstrin, oligosakarida, maltosa, dan D-glukosa (Ariandi, 2016). Enzim ini dapat ditemukan pada tumbuhan, hewan dan mikroorganisme. Enzim mikroba umumnya lebih disukai dalam aplikasi di industri karena kapasitas produksi masal lebih ekonomis dan mikroba mudah dimanipulasi untuk mendapatkan enzim dengan karakteristik yang diinginkan (Abdel-Fattah et. al, 2013). Penggunaan enzim $\alpha$-amilase pada proses industri misalnya industri makanan, industri farmasi, industri tekstil, industri kertas dan industri deterjen (Souza dan Magalhaes, 2010).

Umumnya enzim tidak stabil pada suhu yang tinggi dan $\mathrm{pH}$ yang ekstrem (Goddette et al.,1993). Untuk digunakan dalam industri, diperlukan enzim termostabil, yaitu enzim yang bekerja secara optimum pada suhu antara 60-125 ${ }^{\circ} \mathrm{C}$ (Vielle and Zeikus, 1996), dan bekerja pada rentang $\mathrm{pH}$ yang lebar. Misalnya pada pembuatan sirup gula cair, untuk mengubah pati menjadi dekstrin diperlukan enzim yang stabil dan mempunyai aktivitas yang tinggi pada suhu sekitar $60^{\circ} \mathrm{C}$. Oleh sebab itu, perlu dikembangkan cara cara untuk mendapatkan enzim yang stabil yang dapat digunakan dalam industri.

Hingga saat ini, enzim-enzim dalam bidang industri dengan sifat tersebut, diperoleh dengan cara mengisolasi dari mikroorganisme termofilik atau dengan meningkatkan stabilitas enzim yang diisolasi dari mikroorganisme mesofilik. Menurut Mozhaev and Martinek (1984), stabilisasi enzim yang berasal dari mikroba mesofilik merupakan cara yang lebih disukai, karena isolasi langsung dari mikroorganisme termofilik memiliki kelemahan, yaitu memerlukan perancangan bioreaktor maupun metode pemrosesan baru (Janecek, 1993). Beberapa cara yang dapat digunakan untuk meningkatkan stabilitas enzim adalah penggunaan zat aditif, modifikasi kimia, amobilisasi dan penggunaan rekayasa protein (Illanes, 1999; Yandri et al., 2011; Yandri et al., 2012; Yandri et al., 2013; Yandri et al., 2014; Yandri et al., 2015; Yandri et al., 2018; Yandri et al., 2020).

Penggunaan zat aditif merupakan cara yang paling sederhana yang dapat dipilih untuk meningkatkan stabilitas enzim. Bustos et al. (1999) melakukan penelitian tentang peningkatan

doi: http://dx.doi.org/10.23960/aec.v5.i2.2020.p143-154 
stabilitas termal enzim tripsin dengan penambahan gliserol, xilitol, sorbitol, maltodekstrin dan sukrosa. Peningkatan stabilitas enzim ditandai dengan peningkatan waktu paruh. Peningkatan waktu paruh tertinggi terjadi pada penambahan sorbitol, kemudian diikuti dengan xilitol, gliserol, sukrosa dan maltodekstrin.

Pada penelitian ini dilakukan penambahan zat aditif berupa gliserol terhadap enzim $\alpha$ amilase hasil pemurnian dari A. fumigatus. Gliserol termasuk dalam golongan poliol yang dapat menimbulkan hidrasi air sehingga konformasi protein terjaga dari kemungkinan unfolding (membuka), sehingga dapat meningkatkan kestabilan enzim.

\section{METODE}

\section{Alat dan Bahan}

Adapun alat-alat yang digunakan pada penelitian ini antara lain alat-alat gelas, jarum ose, mikropipet Eppendroff, neraca analitik, lemari pendingin, pembakar spirtus, sentrifuga, tabung sentrifuga, autoclave model S-90N, oven, laminar air flow CRUMA model 9005-FL, shaker inkubator, waterbath, $\mathrm{pH}$ meter dan spektrofotometer UV-VIS Hitachi U2010.

Bahan-bahan yang digunakan adalah pati sagu, PDA (Potato Dextrose Agar), $\mathrm{KH}_{2} \mathrm{PO}_{4}$, $\mathrm{HCl} 1 \mathrm{~N}, \mathrm{FeSO}_{4} .7 \mathrm{H}_{2} \mathrm{O}, \mathrm{CaCl}_{2},\left(\mathrm{NH}_{4}\right)_{2} \mathrm{SO}_{4}, \mathrm{ZnSO}_{4} .7 \mathrm{H}_{2} \mathrm{O}, \mathrm{NaH}_{2} \mathrm{PO}_{4} . \mathrm{H}_{2} \mathrm{O}, \mathrm{Na}_{2} \mathrm{HPO}_{4}, \mathrm{CoCl}_{2}, \mathrm{KI}$, $\mathrm{I}_{2}, \mathrm{Na}_{2} \mathrm{CO}_{3}, \mathrm{NaOH} 0,1 \mathrm{~N}, \mathrm{CuSO}_{4} .5 \mathrm{H}_{2} \mathrm{O}, \mathrm{Na} / \mathrm{K}$-tartrat, folin ciocelteau, Bovine Serum Albumin, amilum, pepton, urea, ammonium sulfat, akuades dan gliserol. Isolat jamur Aspergillus fumigatus diperoleh dari Laboratorium Mikrobiologi Jurusan Biologi Universitas Lampung.

\section{Prosedur}

\section{Produksi dan isolasi enzim}

Sebanyak 2\% media inokulum dari jumlah media fermentasi dimasukkan ke dalam media fermentasi secara aseptis lalu dikocok dalam shaker incubator dengan kecepatan 1500 rpm pada $29{ }^{\circ} \mathrm{C}$ (Yandri et al., 2010). Enzim $\alpha$-amilase diisolasi dengan cara memisahkan antara filtrat dan endapan, menggunakan sentrifugasi dengan kecepatan 5000 rpm selama 15 menit. Filtrat yang diperoleh disebut ekstrak kasar enzim.

\section{Pemurnian}

Pemurnian enzim $\alpha$-amilase dilakukan dengan fraksinasi menggunakan ammonium sulfat (Raul et. al, 2014), kemudian dilakukan dan dialisis menggunakan kantong selofan.

doi: http://dx.doi.org/10.23960/aec.v5.i2.2020.p143-154 


\section{Penentuan aktivitas enzim dan kadar protein}

Aktivitas enzim ditentukan dengan metode Fuwa (Fuwa, 1954) dan Mandels (Mandels et. al., 1976), sedangkan kadar protein ditentukan dengan metode Lowry (Lowry et al., 1951).

\section{Penambahan gliserol pada enzim $\alpha$-amilase hasil pemurnian}

Enzim hasil pemurnian ditambahkan dengan gliserol 0,$5 ; 1$; dan 1,5 $\mathrm{M}$ dengan perbandingan $1: 1$ (enzim : gliserol), menghasilkan enzim hasil pemurnian dan gliserol 0,5 $\mathrm{M}$ (gliserol 0,5 M); enzim hasil pemurnian dan gliserol $1 \mathrm{M}$ (gliserol $1 \mathrm{M}$ ) dan enzim hasil pemurnian dan gliserol 1,5 M (gliserol 1,5 M).

Penentuan pH dan suhu optimum enzim hasil pemurnian dan setelah penambahan gliserol

Untuk mengetahui $\mathrm{pH}$ optimum enzim hasil pemurnian dan setelah penambahan gliserol dilakukan variasi $\mathrm{pH}$, yaitu 4,$5 ; 5 ; 5,5 ; 6 ; 6,5 ; 7 ; 7,5 ;$ dan 8 . Sedangkan penentuan suhu optimum enzim hasil pemurnian dan setelah penambahan gliserol dilakukan dengan variasi suhu inkubasi, yaitu $35,40,45,50,55,60,65$, dan $70{ }^{\circ} \mathrm{C}$.

\section{Uji stabilitas termal}

Penentuan stabilitas termal enzim dilakukan dengan mengukur aktivitas sisa enzim setelah diinkubasi selama periode waktu 100 menit pada suhu dan $\mathrm{pH}$ optimum hasil karakterisasi dengan mengukur aktivitas enzim tiap interval waktu inkubasi 10 menit, selama 100 menit (Yang et al., 1996); Yandri dan Wulandari, 2009). Penentuan waktu paruh $\left(\mathrm{t}_{1 / 2}\right)$, konstanta laju inaktivasi $\left(\mathrm{k}_{\mathrm{i}}\right)$, dan perubahan energi akibat denaturasi $\left(\Delta \mathrm{G}_{\mathrm{i}}\right)$, dilakukan dengan menggunakan persamaan kinetika inaktivasi orde 1 (Kazan et al., 1997).

\section{HASIL DAN PEMBAHASAN}

\section{Isolasi Enzim}

Isolasi enzim menggunakan sentrifugasi menghasilkan ekstrak kasar enzim $\alpha$-amilase yang memiliki aktivitas unit sebesar 2,312 U/mL dan memiliki aktivitas spesifik $0,170 \mathrm{U} / \mathrm{mg}$.

\section{Pemurnian Enzim}

\section{Fraksinasi menggunakan ammonium sulfat}

Grafik pada Gambar 1 menunjukkan hubungan antara konsentrasi ammonium sulfat (\%) dengan aktivitas unit enzim. Aktivitas unit enzim $\alpha$-amilase tertinggi terdapat pada fraksi 40-60\%, yaitu sebesar 3,908 U/mL. Pada fraksi 20-40\% aktivitas unit enzim $\alpha$-amilase sebesar 0,845 U/mL.

doi: http://dx.doi.org/10.23960/aec.v5.i2.2020.p143-154 
Sedangkan pada fraksi $60-80 \%$ masih terdapat enzim $\alpha$-amilase yang terendapkan dengan aktivitas unit yang cukup besar, yaitu 1,12 U/mL. Proses fraksinasi enzim/protein menggunakan ammonium sulfat dengan tingkat kejenuhan tertentu pada hakekatnya merupakan suatu proses pemurnian, karena sifat kelarutan protein yang berbeda dalam air. Protein/enzim yang sukar larut dalam air akan mengendap dengan konsentrasi ammonium sulfat yang rendah.

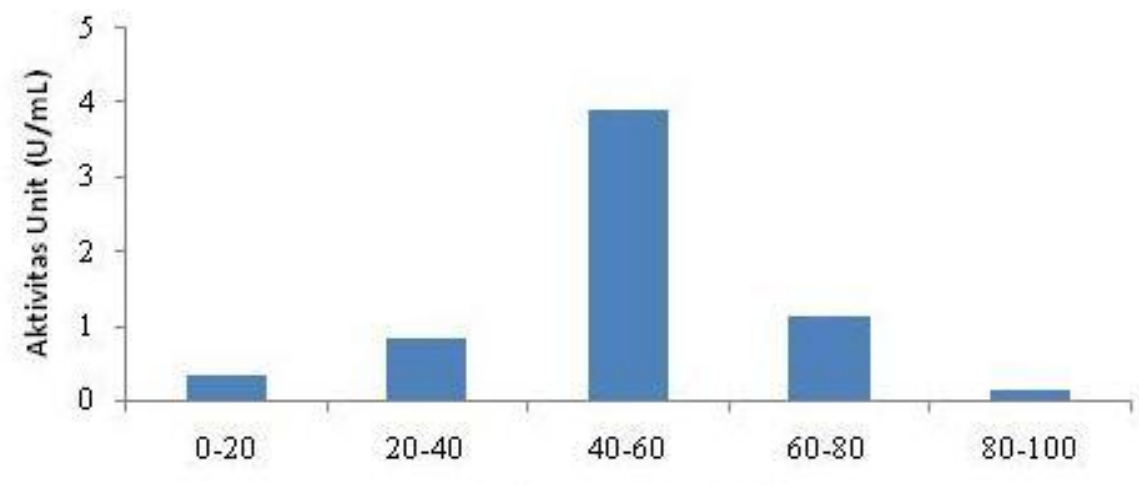

(\%) Ammonium sulfat

Gambar 1. Hubungan antara aktivitas unit enzim $(\mathrm{U} / \mathrm{mL})$ dengan konsentrasi ammonium sulfat $(0-100 \%)$

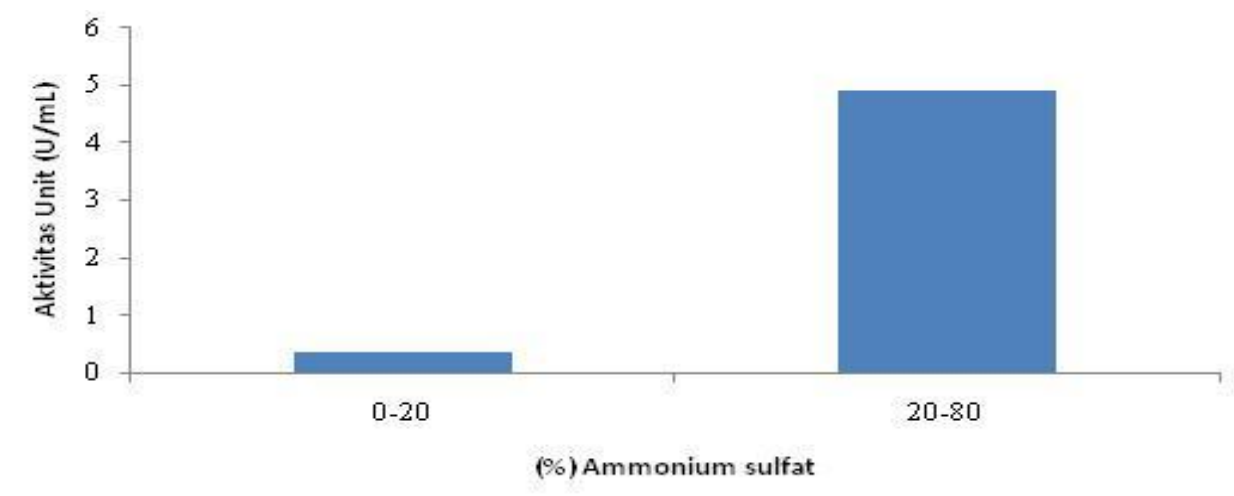

Gambar 2. Hubungan antara aktivitas unit enzim (U/mL) dengan konsentrasi ammonium sulfat $(0-80 \%)$

Pada Gambar 1 dapat dilihat aktivitas spesifik enzim $\alpha$-amilase tertinggi terdapat pada kejenuhan ammonium sulfat $40-60 \%$, artinya enzim $\alpha$-amilase paling banyak mengendap pada konsentrasi ammonium sulfat tersebut. Jika ingin mendapatkan enzim dengan tingkat kemurnian yang tinggi, maka fraksi $40-60 \%$ ini yang digunakan untuk langkah pemurnian berikutnya 
dengan perolehan yang kecil. Jika ingin mendapatkan perolehan tinggi, maka proses fraksinasi selanjutnya dibagi menjadi dua tingkat konsentrasi ammonium sulfat yaitu 0-20\% dan 20-80\% (Gambar 2). Gambar 2 menunjukkan aktivitas unit unit enzim dengan konsentrasi ammonium sulfat 20-80\% sebesar 4,901 U/mL, dengan kadar protein sebesar 7,271 mg/mL dan aktivitas spesifik sebesar $0,679 \mathrm{U} / \mathrm{mg}$.

\section{Dialisis}

Tabel 1 menunjukkan bahwa aktivitas spesifik enzim hasil dialisis mengalami kenaikan menjadi 1,377 U/mg dibandingkan ekstrak kasar enzim dengan aktivitas spesifik 0,170 U/mg. Berdasarkan peningkatan aktivitas spesifik enzim hasil pemurnian dibandingkan dengan ekstrak kasar enzim terjadi peningkatan kemurnian enzim sebesar 8,1 kali. Hasil yang hampir sama dilaporkan Yandri et al. (2010) yang melakukan pemurnian pada enzim $\alpha$-amilase dari Bacillus subtilis ITBCCB148. Hasil penelitian menunjukkan terjadi peningkatan kemurnian enzim hasil fraksinasi dengan ammonium sulfat sebesar 5,7 kali dibandingkan dengan ekstrak kasar enzim. Kadar protein enzim hasil dialisis mengalami penurunan menunjukkan bahwa semakin murni enzim yang dihasilkan. Terjadi peningkatan volume enzim setelah dialisis, sesuai dengan yang dinyatakan Shinde dan Soni (2014) bahwa dialisis akan meningkatkan volume larutan enzim.

Tabel 1. Pemurnian enzim $\alpha$-amilase dari Aspergillus fumigatus

\begin{tabular}{lcccccc}
\hline Tahap & $\begin{array}{c}\text { Volume } \\
\text { Enzim } \\
(\mathbf{m L})\end{array}$ & $\begin{array}{c}\text { Aktivitas } \\
\text { Unit } \\
(\mathbf{U} / \mathbf{m L})\end{array}$ & $\begin{array}{c}\text { Kadar } \\
\text { Protein } \\
(\mathbf{m g} / \mathbf{m L})\end{array}$ & $\begin{array}{c}\text { Aktivitas } \\
\text { Spesifik } \\
(\mathbf{U} / \mathbf{m g})\end{array}$ & $\begin{array}{c}\text { Aktivitas } \\
\text { Total } \\
(\mathbf{U})\end{array}$ & $\begin{array}{c}\text { Kemurnian } \\
(\mathbf{k a l i})\end{array}$ \\
\hline Ekstrak & 2000 & 2,312 & 13,521 & 0,170 & 4624 & 1 \\
Kasar & & & & & & \\
Fraksinasi & 160 & 4,901 & 7,217 & 0,679 & 784,16 & 3,994 \\
Dialisis & 200 & 3,726 & 2,705 & 1,377 & 745,2 & 8,1 \\
\hline
\end{tabular}

\section{Karakterisasi Enzim Hasil Pemurnian dan Setelah Penambahan Gliserol}

\section{Penentuan pH optimum enzim hasil pemurnian dan setelah penambahan gliserol}

Gambar 3 menunjukkan hubungan antara $\mathrm{pH}$ dan aktivitas sisa (\%) enzim hasil pemurnian dan enzim setelah penambahan gliserol. Enzim $\alpha$-amilase hasil pemurnian dan enzim setelah penambahan gliserol dengan tiga variasi konsentrasi memiliki $\mathrm{pH}$ optimum yang sama yaitu pada

doi: http://dx.doi.org/10.23960/aec.v5.i2.2020.p143-154 
pH 5,5. Gambar 3 juga menunjukkan enzim setelah penambahan gliserol 0,5; 1; dan 1,5 M pada pH basa (pH 8) memiliki aktivitas sisa secara berturut-turut sebesar 31,71; 30,54; dan 30,15\%. Sedangkan enzim hasil pemurnian memiliki aktivitas sisa sebesar 14,66\%. Pada gambar juga terlihat enzim setelah penambahan gliserol pada $\mathrm{pH}$ 4,5 (asam) menunjukkan aktivitas sisa yang lebih baik dibandingkan dengan enzim hasil pemurnian. Hasil ini menunjukkan terjadi peningkatan kestabilan enzim setelah penambahan gliserol pada $\mathrm{pH}$ basa maupun $\mathrm{pH}$ asam..

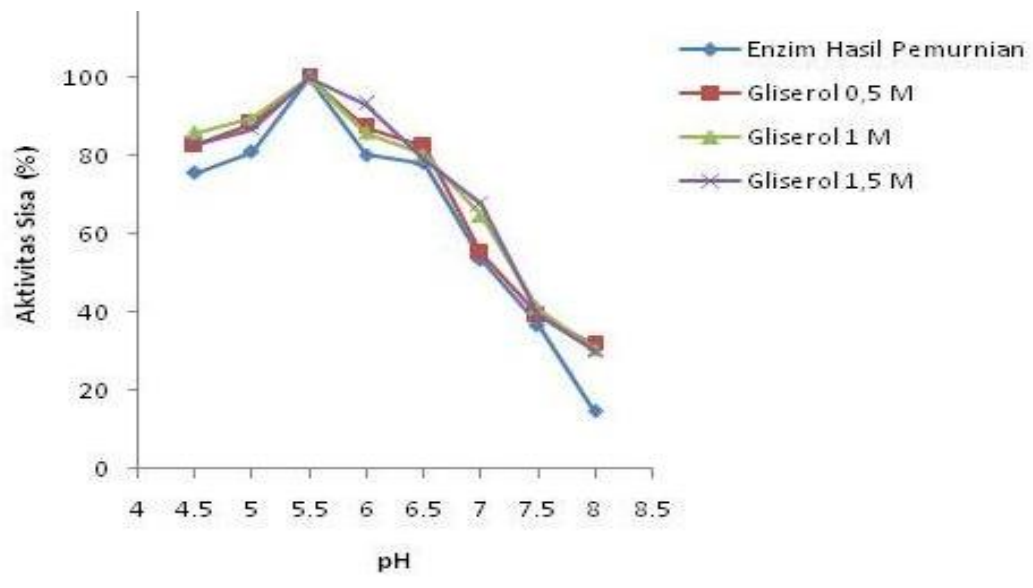

Gambar 3. Hubungan antara $\mathrm{pH}$ dan aktivitas sisa (\%) enzim hasil pemurnian dan setelah penambahan gliserol.

\section{Penentuan suhu optimum enzim hasil pemurnian dan setelah penambahan gliserol}

Gambar 4 menunjukkan hubungan antara suhu dengan aktivitas sisa (\%) enzim hasil pemurnian dan setelah penambahan gliserol yang dilakukan pada suhu 35, 40, 45, 50, 55, 60, 65, dan $70{ }^{\circ} \mathrm{C}$. Untuk suhu kamar tidak dilakukan karena tujuan utama dari penelitian ini adalah untuk mencari enzim yang bersifat termostabil, yaitu enzim yang mampu bekerja dengan baik pada suhu antara antara $60-125{ }^{\circ} \mathrm{C}$ (Vielle and Zeikus, 1996), dan melakukan peningkatan kestabilan enzim dengan penambahan zat aditif, yaitu gliserol. Enzim hasil pemurnian dan enzim setelah penambahan gliserol memiliki suhu optimum yang sama yaitu pada suhu $55{ }^{\circ} \mathrm{C}$ atau tidak mengalami pergeseran suhu optimum. Walaupun tidak terjadi peningkatan suhu optimum, enzim dengan variasi penambahan gliserol 0,5; 1, dan 1,5 M memiliki aktivitas sisa secara berturut-turut sebesar 8,$84 ; 7,37$; dan $9,04 \%$ pada suhu $70{ }^{\circ} \mathrm{C}$. Sedangkan enzim hasil pemurnian pada suhu $70{ }^{\circ} \mathrm{C}$ memiliki aktivitas sisa sebesar 5,29\%. Hasil ini menunjukkan enzim setelah penambahan gliserol lebih stabil pada suhu yang lebih tinggi dibandingkan dengan enzim hasil pemurnian.

doi: http://dx.doi.org/10.23960/aec.v5.i2.2020.p143-154 


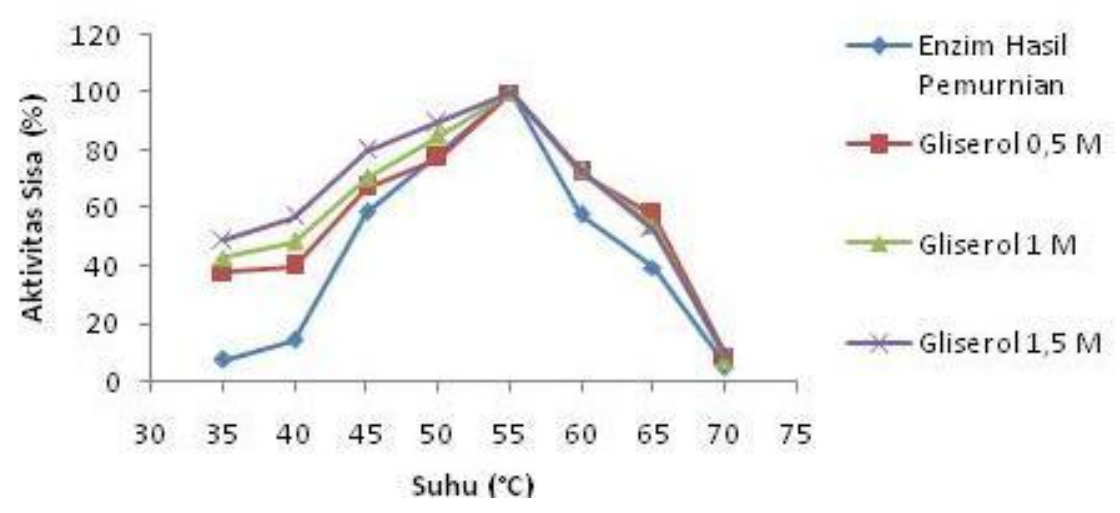

Gambar 4. Hubungan antara suhu dengan aktivitas sisa (\%) enzim hasil pemurnian dan setelah penambahan gliserol.

\section{Stabilitas termal enzim hasil pemurnian dan setelah penambahan gliserol}

Gambar 5 menunjukkan hubungan antara waktu dan aktivitas sisa (\%) enzim hasil pemurnian dan enzim setelah penambahan gliserol yang diinkubasi selama 100 menit pada suhu $55^{\circ} \mathrm{C}$. Aktivitas sisa enzim hasil pemurnian pada menit ke-100 yaitu sebesar 54\% dan aktivitas sisa enzim setelah penambahan gliserol 0,$5 ; 1$; dan $1,5 \mathrm{M}$ secara berturut-turut yaitu sebesar 57 , 60, dan 74\%. Enzim setelah penambahan gliserol lebih stabil dari enzim hasil pemurnian. Hal ini disebabkan oleh struktur enzim setelah penambahan gliserol menjadi lebih terlindungi karena adanya interaksi hidrofobik. Interaksi hidrofobik dapat menyebabkan protein mengalami folding sehingga enzim menjadi lebih stabil dibandingkan dengan keadaan unfolding.

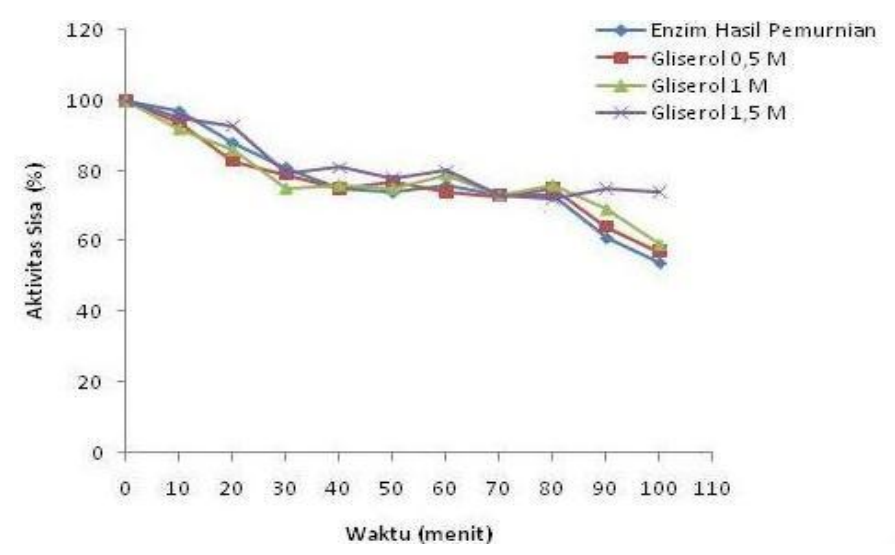

Gambar 5. Hubungan antara waktu (menit) dan aktivitas sisa (\%) enzim hasil pemurnian dan setelah penambahan gliserol.

doi: http://dx.doi.org/10.23960/aec.v5.i2.2020.p143-154 


\section{Penentuan waktu paruh $\left(t_{1 / 2}\right)$, konstanta laju inaktivasi $\left(k_{i}\right)$ dan perubahan energi akibat denaturasi $\left(\Delta \mathbf{G}_{\mathbf{i}}\right)$}

Nilai konstanta laju inaktivasi $\left(\mathrm{k}_{\mathrm{i}}\right)$, waktu paruh $\left(\mathrm{t}_{1 / 2}\right)$ dan perubahan energi akibat denaturasi $\left(\Delta \mathrm{G}_{\mathrm{i}}\right)$ enzim hasil pemurnian dan setelah penambahan gliserol dapat dilihat pada Tabel 2.

Tabel 2. Nilai konstanta laju inaktivasi $\left(\mathrm{k}_{\mathrm{i}}\right)$, waktu paruh $\left(\mathrm{t}_{1 / 2}\right)$ dan perubahan energi akibat denaturasi $\left(\Delta \mathrm{G}_{\mathrm{i}}\right)$ enzim hasil pemurnian dan setelah penambahan gliserol.

\begin{tabular}{lccc}
\hline Enzim & $\mathrm{k}_{\mathrm{i}}(1 / \mathrm{menit})$ & $\mathrm{t}_{\mathrm{l} / 2}($ menit $)$ & $\Delta \mathrm{G}_{\mathrm{i}}(\mathrm{kJ} / \mathrm{mol})$ \\
\hline $\begin{array}{l}\text { Hasil hasil } \\
\text { pemurnian }\end{array}$ & 0,0052 & 133,26 & 106,109 \\
Gliserol 0,5 M & 0,0044 & 157,5 & 106,564 \\
Gliserol 1 M & 0,0038 & 182,36 & 106,964 \\
Gliserol 1,5 M & 0,0031 & 223,54 & 107,520
\end{tabular}

Tabel 2 menunjukkan terjadi penurunan nilai konstanta laju inaktivasi enzim setelah penambahan gliserol, ini menunjukkan bahwa terjadi penurunan laju denaturasi enzim, sehingga enzim dengan penambahan gliserol lebih stabil dibandingkan dengan enzim hasil pemurnian. Nilai $k_{i}$ enzim hasil pemurnian yaitu sebesar 0,0052 menit $^{-1}$ dan enzim setelah penambahan gliserol 0,$5 ; 1 ;$ dan $1,5 \mathrm{M}$ secara berturut-turut yaitu sebesar 0,0044; 0,0038; dan 0,0031 menit ${ }^{-1}$.

Peningkatan waktu paruh pada enzim setelah penambahan gliserol menunjukkan bahwa dibutuhkan waktu yang lebih lama untuk enzim menjadi setengah dari aktivitasnya. Peningkatan nilai waktu paruh menunjukkan enzim lebih stabil untuk digunakan. Waktu paruh enzim hasil pemurnian yaitu sebesar 133,26 menit dan enzim setelah penambahan gliserol 0,5; 1 ; dan 1,5 M secara berturut-turut yaitu sebesar 157,5; 182,36; dan 223,54 menit. Enzim setelah penambahan gliserol 0,$5 ; 1 ; 1,5 \mathrm{M}$ mengalami peningkatan waktu paruh sebesar 1,2; 1,4; dan 1,7 kali dibandingkan dengan enzim hasil pemurnian.

Nilai $\Delta \mathrm{G}_{\mathrm{i}}$ menunjukkan besarnya energi yang dibutuhkan untuk mendenaturasi enzim. Semakin besar nilai $\Delta \mathrm{G}_{\mathrm{i}}$, enzim semakin stabil karena memerlukan energi yang besar untuk mendenaturasinya. Nilai $\Delta \mathrm{G}_{\mathrm{i}}$ enzim setelah penambahan gliserol mengalami peningkatan dari enzim hasil pemurnian. Hal ini menunjukkan bahwa enzim setelah penambahan gliserol lebih

doi: http://dx.doi.org/10.23960/aec.v5.i2.2020.p143-154 
terlindungi terutama pusat aktif enzim sehingga energi yang diperlukan untuk mendenaturasi enzim tersebut semakin tinggi. Nilai $\Delta \mathrm{G}_{\mathrm{i}}$ enzim hasil pemurnian yaitu sebesar $106,109 \mathrm{~kJ} / \mathrm{mol}$ dan enzim setelah penambahan gliserol 0,$5 ; 1$; dan 1,5 M secara berturut-turut, yaitu sebesar 106,564; 106,964; dan 107,520 kJ/mol.

\section{KESIMPULAN}

Enzim hasil pemurnian memiliki aktivitas spesifik 1,377 U/mg meningkat kemurniannya sebanyak 8,1 kali dibanding ekstrak kasar enzim yang memiliki aktivitas spesifik sebesar 0,170 U/mg. Enzim hasil pemurnian memiliki pH optimum 5,5; suhu optimum $55{ }^{\circ} \mathrm{C} ; \mathrm{k}_{\mathrm{i}}=0,0052$ menit $^{-1} ; \mathrm{t}_{1 / 2}=133,26$ menit; dan $\Delta \mathrm{G}_{\mathrm{i}}=106,109 \mathrm{~kJ} / \mathrm{mol}$. Enzim setelah penambahan gliserol 0,5; 1; dan 1,5 M memiliki pH optimum 5,5; suhu optimum $55{ }^{\circ} \mathrm{C}$. Enzim setelah penambahan gliserol 0,5 M memiliki: $\mathrm{k}_{\mathrm{i}}=0,0044$ menit $^{-1} ; \mathrm{t}_{1 / 2}=157,5$ menit; dan $\Delta \mathrm{G}_{\mathrm{i}}=106,564 \mathrm{~kJ} / \mathrm{mol}$. Enzim setelah penambahan gliserol $1 \mathrm{M}$ memiliki: $\mathrm{k}_{\mathrm{i}}=0,0038$ menit $^{-1} ; \mathrm{t}_{1 / 2}=182,36$ menit; dan $\Delta \mathrm{G}_{\mathrm{i}}=106,964 \mathrm{~kJ} / \mathrm{mol}$. Enzim setelah penambahan gliserol 1,5 M memiliki: $\mathrm{k}_{\mathrm{i}}=0,0031$ menit $^{-1}$; $\mathrm{t}_{1 / 2}=223,54$ menit; dan $\Delta \mathrm{G}_{\mathrm{i}}=107,520 \mathrm{~kJ} / \mathrm{mol}$. Penambahan gliserol pada enzim $\alpha$-amilase hasil pemurnian dari A. fumigatus dapat meningkatkan kestabilan enzim sebanyak 1,2-1,7 kali dibandingkan dengan enzim hasil pemurnian ditunjukkan dengan dengan penurunan nilai $\mathrm{k}_{\mathrm{i}}$, peningkatan $\mathrm{t}_{\mathrm{i} / 2}$ dan $\Delta \mathrm{G}_{\mathrm{i}}$.

\section{UCAPAN TERIMA KASIH}

Pada kesempatan ini penulis menyampaikan terima kasih kepada Direktorat Riset dan Pengabdian Masyarakat, Deputi Riset dan Pengembangan, Kementrian Riset, dan Teknologi/Badan Riset dan dan Inovasi Nasional, atas dukungan dana dalam bentuk Penelitian Dasar Sesuai dengan Kontrak Penelitian No.: 179/SP2H/ADM/LT/DRPM/2020.

\section{DAFTAR PUSTAKA}

Abdel-Fattah, Y. R., Soliman, N. A., El-Toukhy, N. M., El-Gendi, H., and Ahmed, R. S., 2013, Production, purification and characterization of thermostable $\alpha$-amylase produced by Bacillus licheniformis isolate AI20, J. of Chem, 2013 1-11.

doi: http://dx.doi.org/10.23960/aec.v5.i2.2020.p143-154 
Ariandi, M., 2016, Pengenalan Enzim Amilase (Alpha-Amylase) dan Reaksi Enzimatisnya Menghidrolisis Amilosa Pati Menjadi Glukosa, Jurnal Dinamika, 7(1) : 74-82.

Bustos, R.O., Romo, C.R., and Healy, M.G., 1999, Stabilisatioan of Trypsin-Like Enzymes from Antarctic Krill : Effect of Polyols, Polysaccharida and Proteins. Journal of Chemical Technology \& Biotechnology, Univ. Santiago de Chile, Chile, Volume 65. P. 193-199.

Fuwa, H., 1954, A new method for Microdetermination of Amylase activity By the use of Amylose as the substrate. The Journal of Biochemistry, 41.583-603.

Goddette, D.W., Christianson, T., Ladin, B.F., Lau, M., Mielenz, J.R., Pae, C.,Reynolds, R. B., Yang, S.S., and Wilson, C.R., 1993, Strategy and implementation of a system for protein engineering, J. Biotechnol., 28, 41-54.

Irdawati., Fifendy, M., dan Yenti, N., 2015, Penapisan Bakteri Termofilik PenghasilEnzim Amilase Dari Sumber Air Panas Sapan Sungai Aro Kabupaten Solok Selatan., Eksakta.1. 73-81.

Illanes, A., 1999. Stability of Biocatalysts. Review Article. EJB Electronic Journal of Biotechnology. Univ. Catolica de Valparaiso. Chile. 2 (1). 1 - 9.

Janecek, S., 1993, Strategies for obtaining stable enzymes, Process Biochem., 28, 435-445.

Kazan, D., Ertan, H., and Erarslan, A., 1997, Stabilization of Escherichia coli Penicillin G acylase agains thermal Inactivation by cross-linking with dextran dialdehyde polymers.Appl. Microbiol Biotechnol, 48: 191-197.

Lowry, O. H., Rosebrough, N. J., , Farr, A. L., and Randall, R.J., 1951, Protein measurement with the folin phenol reagent, J. Biol. Chem., 193:265-275.

Mandels, M., Andreotti, R., and Roche, C., 1976, Measurment of saccharifying cellulose.Biotech \&Bioeng.symp, 6 21-33( New York: John Willey and Sons Inc).

Mozhaev, V. V. and Martinek K., 1984, Structure-stability relationship in proteins: New approaches to stabilizing enzymes, Enzyme Microb. Technol., 6, 50-59.

Raul, D., Biswas T., Mukhopadhyay, S., Das, S. K., and Gupta, S., 2014, Production and partial purification of alpha amylase frombacillus subtilis (mtcc 121) using solid state fermentation, Biochem. Research Int., 1-5.

Shinde, S. and Soni, R., 2014. Production and partial purification of $\alpha$-amylase from bacterial strains, International Journal.Genetic Engineering and Biotechnology, 5(1) 57-62.

Souza, P.M. and Magalhaes, P.O., 2010, Application microbial $\alpha$-amylase in industry_a review. Brazilian Journal of Microbiology, 41 (4) 850 - 861.

Vieille, C. and Zeikus, J. G., 1996, Thermozymes: Identifying molecular determinant of protein structural and functional stability, Tibtech., 14 (6), 183-189.

Yandri dan Wulandari, P., 2009, Pengaruh Penambahan Sorbitol terhadap Stabilitas Termal Enzim $\alpha$-amilase dari Rhizopus oryzae, J. Sains MIPA. 15 (2), 111-118.

doi: http://dx.doi.org/10.23960/aec.v5.i2.2020.p143-154

Anal.Environ.Chem.

153 
Yandri, Suhartati,T., and Hadi, S., 2010, Purification and Characterization of Extracellular $\alpha$ Amilase Enzyme from Locale Bacteria Isolate Bacillus Subtilis ITBCCB148, Eur. J .Sci. Res. 39 (1), 64-74.

Yandri, Anggraini, N., Suhartati, T., and Hadi, S., 2011, Chemical Modification of $\alpha$-amylase from Locale Bacteria Isolate Bacillus subtilis ITBCCB148 with Glyoxylic Acid, Oriental Journal of Chemistry, 27 (3), 985 - 990.

Yandri, Sundari, E.S., Suhartati, T., and Hadi, S., 2012, The Chemical Modification of $\alpha$ amylase from Locale Bacteria of Bacillus subtilis ITBCCB148 Using Citraconic Anhydride, Oriental Journal of Chemistry, 28 (4), 1613 - 1618.

Yandri, Amalia, P., Suhartati, T., and Hadi, S., 2013, Effect of Immobilization Towards Thermal Stability of $\alpha$-Amylase Isolates from Locale Bacteria Isolate Bacillus subtilis ITBCCB148 with Calcium Alginate, Asian Journal of Chemistry, 25 (12), 6897-6899.

Yandri, Rachmawati, R., Suhartati, T., and Hadi, S., 2014, The Chemical Modification of Cellulase from Locale Bacteria Isolate Bacillus subtilis ITBCCB148 with Glyoxylic Acid, Journal Of Pure And Applied Microbiology, 8 (5), p. 3675-3680.

Yandri , Amalia, P., Suhartati, T., and Hadi, S., 2015, The Chemical Modification of Cellulase Obtained from Bacillus subtilis ITBCCB148 With Dimethyladimipidate, Biosciences Biotechnology Research Asia, 12(3), 2089-2093.

Yandri, Suhartati, T., Yuwono, S. D., Qudus, H.I., Tiarsa, E.R., Hadi, S., 2018, Immobilization of $\alpha$-amylase From Bacillus subtilis ITBCCB148 Using Bentonit, Asian Jr. of Microbiol. Biotech. Env. Sc. 20 (2), 487-492.

Yandri, Suhartati, T., Satria, H., Widyasmara, A., and Hadi, S., 2020, Increasing Stability of $\alpha$-amylase Obtained from Bacillus subtilis ITBCCB148 by Immobilization with Chitosan, Mediterranean Journal of Chemistry, 10(2), 155-161.

Yang, Z., Domach, M., Auger, R., Yang, F. X., and Russel, A.J., 1996, Polyethylene glycolinduced stabilization of subtilisin, Enzyme Microb. Technol., 18, 82-89.

doi: http://dx.doi.org/10.23960/aec.v5.i2.2020.p143-154 